\title{
KEBIADABAN MANUSIA DALAM TETRALOGI NOVEL EKA KURNIAWAN KAJIAN STILISSOSIO SASTRA
}

\author{
Sukirno \\ SMP NU Al-Hidayah, Maduran, Lamongan \\ pos-elsoechirno.la@gmail.com
}

\begin{abstract}
Abstrak: Tujuan penelitian ini adalah mendeskripsikan (1) penggunaan bahasa kebiadaban, (2) bentuk kebiadaban manusia, (3) pandangan dunia pengarang terhadap kebiadaban manusia, (4) dampak kebiadaban manusia, (5) jalan keluar kebiadaban manusia dalam tetralogi novel Eka Kurniawan. Penelitian ini menggunakan kajian stilistika dan sosiologi sastra dengan menggunakan teori heurmeneutik dan mimesis untuk menganailis tetralogi novel karya Eka Kurniawan. Penelitian ini menggunakan metode deskriptif kualitatif dengan pendekatan stilistika dan sosiologi sastra. Data utama penelitian ini berupa kosakata, gramatika, dan struktur teks. Hasil penelitian ditemukan bahwa banyak penggunaan kata vulgar atau minoritas. Ditemukan bentukbentuk kebiadaban seperti penipuan, penindasan/ penyiksaan, pertengkaran, pemerkosaan dan pembunuhan. Dalam pandangan dunia pengarang ditemukan kekuasaan, tipu daya dan penderitaan. Dampak kebiadaban ditemukan balas dendam, pertengkaran dan pembunuhan. Sementara jalan keluar dari kebiadaban bisa dilakukan dengan cara pendidikan / sekolah, religius, sabar dan saling tolong menolong.
\end{abstract}

Kata kunci: kebiadaban, tetralogi novel, stilistika, sosiologi sastra 


\section{PENDAHULUAN}

Di era globalisasi ini, tingkat kejahatan dan kriminalitas di masyarakat Indonesia semakin meningkat mengikuti pertumbuhan ekonomi dan industri yang cukup berkembang. Hal tersebut bisa dilihat di media cetak maupun elektronik yang memberitakan mengenai maraknya kejahatan yang terjadi di Tanah Air. Fenomena tersebut mulai dari tindak pidana kekerasan, penipuan, penyiksaan, pertikaian/perkelahian, pemerkosaan hingga pembunuhan, sebagai suatu kenyataan sosial.

Peristiwa kekerasan yang terjadi di masyarakat Indonesia terus mengalami perkembangan yang diiringi dengan gaya dan model yang sangat beragam, dari cara yang paling sederhana sampai yang sangat tercanggih. Terkadang kekerasan itu dilakukan dengan cara yang keji seperti disiksa lebih dahulu, dibakar dan bahkan dibunuh. Tindak kekerasan sering terjadi dalam kehidupan masyarakat, sehingga tindak kekerasan seolah-olah telah melekat dalam diri seseorang guna mencapai tujuan hidup. Kekerasan adalah semua tindakan yang merugikan korban, baik itu dipukul, disiksa, ditipu atau dibunuh" (Adrianus Meliala, 2006: 58).

Lebih ironis lagi adalah ternyata motif dari kekerasan itu kadang-kadang hanya dilatar belakangi oleh masalahmasalah yang sederhana, misalnya karena uang sekian rupiah, saling mengejek, sedikit hak miliknya diambil atau diganggu dan masalah-masalah lain yang sebenarnya dapat diselesaikan dengan kedewasaan dan kejernihan berfikir. Menurut Gabriel Tarde, manusia itu pada dasarnya individualis, tetapi berkat kemampuan untuk meniru (imitasi), berbagai peniruan yang dilakukannya membentuk jalinan interaksi sosial dan pada gilirannya tersusun kehidupan sosial. Bahkan masyarakat itu pun merupakan buah peniruan yang timbul dari berlangsungnya imitasi berkelanjutan dalam proses sosial (Marpaung, 1999: 59).

dan Hal tersebut cukup menggelisahkan masyarakat. Kejahatan tersebut tidak hanya timbul dari dorongan kejiwaan si pelaku sendiri, tetapi juga kerap timbul dari dorongan luar seperti ingin lari dari tanggung jawab. Oleh karenanya Eka Kurniawan (seorang sastrawan) lewat karya sastra (novel) mengungkap fenomena kekerasan (kebiadaban manusia) yang kerap terjadi di dalam masyarakat Indonesia mulai dari penipuan, penindasan, pertengkaran, pemerkosaan, dan pembunuhan.

Sebuah karya sastra tidak lepas dari kehidupan umat manusia. Di samping mengungkapkan masalah kehidupan manusia, karya sastra juga dapat dikatakan sebagai suatu pernyataan dari cita-cita yang berhubungan dengan realitas objektif tersebut yang diungkapkan dalam salah satu wadah artistik. Melalui karyanya pengarang ingin menyuarakan tanggapannya secara evaluatif terhadap kenyataan di sekitarnya dan mencoba menawarkan sesuatu yang diidealkan. Pengarang umumnya tampil sebagai pembela kebenaran dan keadilan, dan memperjuangkan hal-hal yang diyakini kebenarannya (Nurgiyantoro, 2005 : 25).

Karya sastra tidak hanya sebuah imajinasi yang dapat dinikmati, tetapi bisa dipelajari mengenai: sosiologi, psikologi, adat istiadat, moral, budi pekerti, agama, tutunan masyarakat, dan tingkah laku manusia pada suatu masa. Banyak hal yang bisa kita ambil sebagai pelajaran yang berharga dari sebuah karya sastra (Sangidu, 2004: 43).

Salah satu karya sastra yang banyak diketemukan kemiripan dengan fakta yang ada dengan dunia nyata adalah novel. Isi dalam novel dapat dipastikan 
terinspirasi dari dunia nyata yang diimajinasikan oleh pengarang. Pengalaman dan lingkungan yang terjadi di sekitar pengarang menjadi sumber inspirasi dalam proses kreatif pembuatan novel. Pengarang mengolah realitas sosial menjadi karya fiksi. Pengarang memiliki kepekaan dalam memilih bahan berdasarkan realitas sosial. Pengarang berhak mengemukakan pandangan pribadinya. Pandangan pribadi pengarang dalam karyanya itu pun tidak lepas dari konteks masyarakat (Sariban, 2015: 112).

Novel merupakan karya sastra atau fiksi yang menyuguhkan cerita mengenai sebuah peristiwa dan latar yang tersusun secara cermat. Kandungan dalam novel memiliki fungsi indah dan berguna, sehingga novel tidak hanya bersifat seni, tetapi bisa diketemukan nilai-nilai kemanusian dan pesan moral di dalamnya. Nilai-nilai kemanusian yang ada dalam novel membentuk sistem sosial dalam masyarakat melalui rangkaian cerita yang disampaikan pengarang.

Salah satu novel yang mampu mengangkat tentang kehidupan sistem sosial masyarakat adalah tetralogi novel karya Eka Kurniawan yang mengungkapkan kekerasan (kebiadaban) di masyarakat.

Pengupasan kebiadaban manusia yang terjadi dalam tetralogi novel karya Eka Kurniawan menggunakan pendekatan stilistika dan sosiologi sastra. Hal ini karena kisah kehidupan dalam novel ini sarat dengan berbagai penyiksaan dan ketidakpedulian sosial yang mencerminkan suatu kondisi masyarakat. Penggunaan bahasa yang kerap kita jumpai dalam novel adalah bahasa minoritas yang secara tidak langsung menunjukkan keadaan yang syarat dengan kekerasan (kebiadaban).

Eka Kurniawan adalah pengarang muda yang lahir di Tasikmalaya tahun
1975. Ia menyelesaikan studi dari Fakultas Filsafat Universitas Gajah Mada tahun 1999, dengan skripsi yang diterbitkan menjadi buku berjudul Pramoedya Ananta Toer dan Sastra Realisme Sosialis. Novel $O$ merupakan salah satu novel Eka Kurniawan yang ditulis dalam waktu yang cukup panjang, delapan tahun, 2008-2016. Selain mendapat World readers Award, Eka Kurniawan masuk nominasi The Man Booker Prize Internasional 2016 lewat novelnya Lelaki Harimau atau Man Tiger dalam Bahasa Inggris. Karyanya yang lain, Cantik Itu Luka telah diterjemahkan ke dalam 24 bahasa. Juga ada Seperti Dendam, Rindu Harus Dibayar Tuntas.

Oleh karena itu, berdasarkan latar belakang di atas bisa disimpulkan bahwa judul penelitian iniadalah Kebiadaban Manusia dalam Tretalogi NovelEka Kurniawan (Kajian Stilissosio Sastra).Dalampenelitian ini akan dipaparkan gaya Bahasa, bentuk dan dampak kebiadaban serta realitas kehidupan sosialyang terjadi dalam novelyang bisa menjadi pembelajaran nilai moral dan kemanusiaan kepada pembaca.

\section{METODE}

Penelitian ini menggunakan metode deskriptif kualitatif dengan pendekatan stilistika dan sosiologi sastra. Penelitian kualitatif adalah prosedur penelitian yang menghasilkan data deskriptif berupa kata-kata tertulis atau lisan dari orang-orang dan perilaku yang diamati (Bogdan dan Taylor dalam Moleong, 1990: 31). Penelitian ini juga dilandasi teori heurmeneutik, mimesis dan strukturalisme genetik.

Penelitian ini menggunakan teknik pengumpulan data berupa teknik pustaka, simak, dan catat. Teknik pustaka adalah teknik menggunakan sumbersumber tertulis untuk memperoleh data. 
Teknik simak adalah suatu metode pemerolehan data yang dilakukan dengan cara menyimak suatu penggunaan bahasa (Sudaryanto dalam Mahsun, 2005: 90).

Teknik simak dan teknik catat berarti peneliti sebagai instrumen kunci melakukan penyimakan secara cermat, terarah, dan teliti terhadap sumber data primer yakni sasaran peneliti yang berupa teks tetralogi novel dalam memeroleh data yang diinginkan. Istilah menyimak di sini tidak hanya berkaitan dengan penggunaan bahasa secara lisan, tetapi juga penggunaan bahasa secara tertulis. Hasil penyimakan kemudian dicatat sebagai sumber data. Dalam data yang dicatat itu disertakan kode sumber datanya untuk mengecek ulang terhadap sumber data ketika diperlukan dalam rangka analisis data (Subroto, 1992: 42).

Dalam penelitian ini istilah yang lebih tepat digunakan adalah metode observasi atau pengamatan. Observasi/ pengamatan secara mendalam terhadap fenomena kebahasaan dalam tetralogi novel Karya Eka Kurniawan. Pengamatan dilakukan agar memeroleh data utama menjawab fokus penelitian dan yang sesuai dengan tujuan penelitian.

\section{HASIL DAN PEMBAHASAN Bahasa Vulgar/Minoritas}

Dalam karya sastra ada banyak diksi antara lain kata konotatif, kata konkret, kata serapan dari bahasa asing, kata sapaan khas dan nama diri, kata dengan objek realitas alam, dan kata vulgar. Adapun menurut Yusuf (dalam Al Ma'ruf, 2010: 35) kata vulgar adalah kata-kata yang carut dan kasar atau kampungan. Fenomena dalam tetralogi novel Eka Kurniawan menunjukkan betapa carut marutnya negeri ini yang ditunjukkan beberapa penggalan kata dalam Novel $\mathrm{O}$ berikut ini :

"Aku mencari bocah sinting itu”, (Kurniawan, 2016:145)
Cari Wulandari dan gorok lehernya", (Kurniawan, 2016:130)

Si sopir taksi tak lagi bisa menahan tawa. Si lelaki di belakang langsung menjotos kepalanya. "Tutup mulutmu.Aku tidak melawak, Tolol. (Kurniawan, 2016: 364)

Kutipan di atas menunjukkan bahwa bangsa Indonesia terutama masyarakat minoritas selalu menggunakan kata-kata vulgar, seperti bocah sinting, gorok lehernya, tolol. Banyak faktor yang memengaruhi penggunaan bahasa minor diantaranya faktor teman dan faktor lingkungan yang banyak memengaruhi. Dalam Novel SDRHDT juga banyak penggunaan katakata vulgar seperti pada kutipan berikut: Tanpa mengatakan apa pun, Ki Jempes, lelaki tua buta itu, mencambuk punggungnya dengan rotan tersebut. Suaranya terdengar mengiris. "Lonte!", (Kurniawan, 2016:151)

Deskripsi kebiadaban memang banyak kita temui dalam tetralogi novel Eka Kurniawan. Data (4) dalam penggalan novel Seperti Dendam Rindu Harus Dibayar Tuntas ditemukan katakata tua buta, mencambuk, mengiris, lonte menunjukkan bahasa yang khas, yang sering digunakan pemakainya. Kurniawan dalam novel Lelaki Harimau juga menginggung penggunaan gaya bahasa sundal seperti dalam kutipan berikut :

"Perempuan sundal!" pekik komar bin syueb, sambil melemparkan asbak seng ke mukanya, dan pergi meninggalkan mereka. (Kurniawan, 2016:144)

Dalam novel ke empat Cantik Itu Luka yang di tulis Eka Kurniawan juga banyak penggunaan diksi vulgar, seperti dalam kutipan berikut:

Perempuan-perempuan itu menjerit dan memandang Dewi Ayu dengan wajah idiot mereka. Melahirkan seorang bayi buruk rupa adalah kebiadaban dan meninggalkannya begitu saja jauh lebih biadab. Tapi mereka tak mengatakannya, hanya membujuk untuk tak berharap mati secara konyol. Mereka bercerita tentang orang-orang yang hidup lebih dari seratus tahun, dan Dewi Ayu masihlah terlampau muda untuk mati. (Kurniawan, 2015: 6) 
Data tersebut terdapat kata vulgar 'sinting', 'gorok', 'tolol', 'lonte', 'sundal', 'biadab'. Kata-kata vulgar yang terdengar kasar pada data tersebut digunakan oleh pengarang untuk melukiskan perasaan banyaknya kejahatan di bangsa ini, marah dengan atau jengkel pada teman dan lingkungan, dan perasaan tidak suka terhadap siapa saja (mitra tutur).

\section{Bentuk Kebiadaban}

Bangsa ini sudah banyak yang tidak jujur, segala macam hal perbuatan dilakukan demi mendapatkan keuntungan sepihak. Penipuan adalah cara yang paling ampuh, yang paling cocok mendapatkan kekuasaan. Penipuan dalam tetralogi novel Kurniawan sangat banyak ditemukan seperti dalam kutipan novel $O$ sebagai berikut :

"Kau yang membuatku tolol." Toni hendak masuk ke kamar mandi. Ketika mendengar Dara mengatakan itu, ia berhenti dan berbalik. Mendekati si gadis dan tangannya melayang menampar pipi Dara. (Kurniawan, 2016: 375)

Dalam kutipan data tersebut ditemukan bahwa bagaimana cara Toni berbohong kepada si gadis. Toni seakan masuk kamar mandi, namun sebelum masuk ia berbalik seakan baik kepada si gadis, tidak tahunya semua kebaikan yang diberikan hanya di awal saja. Setelah si gadis terjebak masuk dalam perangkatnya Toni kemudian menyiksa si gadis dengan cara menampar pipi Dara.

Adapun bentuk penyiksaan seperti yang digambarkan Kurniawan dalam kutipan novel $O$ sebagai berikut :

Betalumur berdiri dengan kepala bocor dan darah menghiasi wajahnya. Matanya redup. Pijakan kakinya goyah. Bibirnya bengkak. Tangannya hanya menggantung. Mereka menyeret Betalumur, membawa si anjing kecil, dan menghancurkan segala yang ada di sirkus topeng monyet itu. (Kurniawan, 2016: 141)

Untuk mengorek informasi dari sopir taksi, seorang polisi yang bernama Sobar memukuli sopir taksi itu berkali- kali. Seorang sopir taksi sangat menderita karena dihajar oleh penumpang yang tidak dikenalnya. Dia dijotos berkali-kali sampai babak belur. Dia dipukuli sampai pecah bibirnya. Dia dipukuli sampai terkapar. Dia diseret. Sopir taksi yang malang. Disiksa penumpangnya sampai terkapar, kemudian diseret tubuhnya dan didorong masuk ke mobilnya.

Perdebatan yang tercela adalah usaha menjatuhkan orang lain dengan menyerang atau mencela pembicaraan atau tindakannya, emnganggapnya bodoh dan tidak akurat. Bentuk pertengkaran dideskripsikan pada kutipan novel Kurniawan yang berjudul $O$ sebagai berikut:

"Mampus kau!" terdengar teriakan Betalumur sesaat setelah ia melompat dan berhasil menangkap si anjing kecil. "Setan, sundel, pocong, diam kau." Kirik memberontak, menggeliat, menendang, mencoba mencakar, mencoba menggigit, tapi pegangan Betalumur sangat kuat. Betalumur menerjang, dan kali ini kedua tangannya berhasil mencengkeram leher Kirik, membuat anjing kecil itu mengaing panjang. "Anjing panggang! Setidaknya malam ini kau bisa membuat kenyang perutku." (Kurniawan, 2016: 40-41)

Pukulan balok kayu ke kepala, tancapan tombak ke tubuh yang dilakukan berkali-kali pada babi. Tergambar pada peristiwa ketika ada Babi. Rohmat Nurjaman salah seorang yang menyiksa babi dengan sangat kejam. Rohmat Nurjaman ingin menyaksikan apa yang menjadi kecurigaannya selama ini. Tidak mungkin di Jakarta yang seperti itu ada babi. Pikiran Rohmat Nurjaman kembali tertuju kepada seorang lelaki yang telah merebut pacarnya. Dia kelihatannya tidak mempunyai pekerjaan, tidak mempunyai usaha, tetapi mempunyai duit banyak.

Novel $O$ karya Eka Kurniawan memberi gambaran bagaimana pemerkosaan yang dialami oleh $\mathrm{Ma}$ Kungkung sewaktu dia datangdari pedalaman Jawa. Pada waktu musim 
kering yang berkepanjangan dan tidak ada pekerjaan apa pun di sawah maupun ladang, Ma Kungkung memutuskan untuk pergi ke Jakarta bersama seorang tetangga kampung. Si tetangga sudah tiga tahun bekerja menjadi tukang mengasuh bayi di satu rumah, dan berjanji mencarikannya pekerjaan di rumah lain. Ma Kungkung bisa mencuci, memasak, mengganti popok bayi, membersihkan rumah, bahkan menebang pohon jika diperlukan. Banyak yang butuh orang seperti dia, kata si tetangga kampung. Sesampai di terminal Kampung Rambutan $\mathrm{Ma}$ Kungkung menjadi korban pemerkosaan. Tiga orang preman memperkosanya secara bergiliran.

Sialnya, ketika sampai di terminal Kampung Rambutan, dalam keriuhan penumpang bus yang datang dan pergi, ia terpisah dengan si tetangga kampung. Ia kebingungan, dan dasar tolol (demikian ia mengejek dirinya sendiri), Ma Kungkung tak berani bertanya kepada siapasiapa. Hanya berkeliling terminal dari ujung ke ujung, tanpa berhasil menemukan tetangganya. Tiga orang preman merampok bawaannya. Yang paling brengsek, mereka memerkosanya bergantian, lalu meninggalkannya di satu pembuangan sampah. (Kurniawan, 2016: 97)

Pemerkosaan kepada seorang perempuan yang dilakukan oleh tiga preman secara bergiliran. Pemerkosaan tentu menyakitkan. Lebih-lebih dialami oleh seorang perempuan yang sedang dalam kebingungan dan ketakutan. Seorang perempuan dari desa yang baru tiba di sebuah kota besar, Jakarta. Tidak tahu alamat di mana yang akan dituju, barang bawaannya dirampok kemudian diperkosa secara bergiliran oleh tiga orang preman.

Pembunuhan adalah sutau tindakan untuk menghilangkan nyawa seseorang dengan cara melangggar hukum, maupun yang tidak melawan hukum. Pembunuhan biasanya dilatarbelakangi oleh bermacam-macam motif, misalnya politik, kecemburuan, dendam, membela diri, dan sebagainya. Adapun pembunuhan bisa dilakukan dengan berbagai cara. Misalnya dengan cara membungkam hidungnya, atau dengan tindakan kekerasan menganiaya, menusuk perutnya dengan pisau, memotong atau menggorok lehernya, dan masih banyak lagi motif pembunuhan. Dalam kutipan tetralogi novel Kurniawan yang berjudul O sebagai berikut :

Sebelum sampai rumah sakit, Jarwo Edan mati, Tapi sebelum mati, Jarwo Edan berhasil mengatakan pesan terakhirnya: "Cari Wulandari dan gorok lehernya”, (Kurniawan, 2016:130)

Data di atas mendeskripsikan bagaimana cara penguasa melakukan tindakan kekerasan. Siapa saja yang melawan dan tidak menurut dengan semua perintahnya akan dibunuh. Juga siapa saja teman dari orang-orang yang tidak mau diperintah akan dilenyapkan dengan cara digorok lehernya. Berbagai cara dilakukan penguasa untuk melenyapkan nyawa seseorang. Misalnya pada kutiban data (32) penguasa membunuh dengan cara menyuruh orang. Preman atau ketua kelompok dari sekumpulan gerombolan yang siap untuk membunuh siapa saja disebut dengan pembunuh bayaran.

\section{Pandangan Dunia Pengarang}

Eka Kurniawan memberikan beberapa gambaran terkait keadaan bangsa Indonesai. Sebagai bentuk-bentuk kekerasan/kebiadaban bangsa ada beberapa hal yang sangat memengarui, diantaranya adalah kekuasaan, tipu daya, dan penderitaan.

Era penjajahan memunculkan pemikir-pemikir handal dari pihak subaltern. Dalam novel Cantik Itu Luka diketahui adanya Kamerad Kliwon yang sangat cerdas yang hidup dengan selalu memikirkan cara untuk membuat masyarakat lebih sejahtera. Kamerad Kliwon, bukan seorang pejuang layaknya Shodancho. Namun, ia menjadi orang 
yang berpengaruh dalam kebangkitan masyarakat pribumi pasca proklamasi. Ia pemikir ulung di era pasca penjajahan.

"Ia kadang bertanya-tanya juga apakah sudah merupakan nasib para revolusioner untuk menjalani kehidupan yang sunyi dengan kepala yang melulu dijejali gagasan-gagasan tentang revolusi. Beginilah mungkin ia akan menjalani hidup: ia bercinta sambil memikirkan revolusi, mabuk revolusi, makan revolusi, dan bahkan buang tai revolusi." (Kurniawan, 2015: 323).

Kamerad Kliwon sering berpikir tentang nasib nelayan yang kurang makmur. Ia juga membuka taman bacaan untuk orang-orang, meskipun pada akhirnya taman bacaan itu ditutup karena ada isu bahwa komunis meracuni masyarakat dengan bacaan-bacaan tidak mendidik. Ia kemudian hidup sebagai orang biasa dan bekerja membuat kolor untuk kehidupan keluarganya. Kolor tersebut banyak disukai dan menjadi produk khas Halimunda yang merupakan daerah wisata pantai di Indonesia. Lalu, masyarakat beramai-ramai mengembangkan kolor di Halimunda. Dan suatu kali, ketika wisata pantai Halimunda akan diprivatisasi atas kebijakan pemerintah setempat, Kamerad Kliwon berjuang agar pemerintah membatalkan kebijakan tersebut. Hal ini dilakukan untuk penduduk Halimunda yang bergantung hidup pada pantai Halimunda.

Terjadinya kekerasan bermula dari adanya pola relasi kekuasaan yang timpang antara atasan dengan bawahan. Kondisi ini tidak jarang mengakibatkan tindak kekerasan oleh masyarakat kecil terhadap lingkungannya justru dilakukan sebagai bagian dari penggunaan otoritas yang dimilikinya. Banyak teori ataupun penelitian yang memperlihatkan sumbersumber kekuasaan penguasa, yang pada gilirannya kemudian melahirkan kekerasan terhadap orang lain, khususnya masyarakat kecil. Kekuasaan sistem patriarki adalah biang keladi di balik diskriminasi atau kekerasan terhadap orang kecil. Akibatnya masyarakat kecil merasakan penderitaan seperti dalam kutipan novel $\mathrm{O}$ karya Kurniawan sebagai berikut:

Si sopir taksi tak lagi bisa menahan tawa. Si lelaki di belakang langsung menjotos kepalanya. "Tutup mulutmu. Aku tidak melawak, Tolol. (Kurniawan, 2016: 364)

Penjelasan penulis mengenai penderitaan terdapat dalam kutipan laen yang terdapat dalam novel Kurniawan yang berjudul Seperti Dendam Rindu Harus Dibayar Tuntas sebagai berikut :

$\mathrm{Ki}$ Jempes kembali mengangkat rotan, mengayunkannya ke permukaan punggung itu, sekali, dua kali, tiga kali, dengan gerakan yang makin lama makin cepat. Dan tanda merah menyilang di sana-sini, di punggung Ajo Kawir. Si boca hanya menggeram, sesekali memekik, dan beberapa kali memaki" "Lonte-lonte!". (Kurniawan, 2016: 151-152)

Penderitaan yang dialami Ajo Kawir yang disiksa oleh $\mathrm{Ki}$ Jampes sangat tidak manusiawi. Pasalnya masalah sederhana yang dilakukan oleh Ajo Kawir yaitu mengintip orang gila di rumah tengah ladang. Namun karena $\mathrm{Ki}$ Jampes punya niat jelek terhadap orang gila dan saat itu Ajo Kawir di sana, mengetahui langsung kejadian itu. Maka tanpa rasa iba Ki Jampes melayangkan rotan mencambuknya berulang kali.

\section{Dampak Kebiadaban}

Dalam dendam dilakukan untuk mencapai tujuan yang sangat berarti, bahkan memikirkan rencana balas dendam memberikan kepuasan. Balas dendam telah menjadi bagian dari perilaku manusia hampir sepanjang kehidupan di bumi. Sastra telah memggunakannya sepanjang sejarah, dari tragedi Yunani seperti trilogi Ore s teia karya Aeschylus di mana Orestes ingin membunuh ibunya untuk membalas dendam ayahnya sampai Hamlet karya Shakespare. 
Dalam novel CIL diceritakan, kebencian Ma Gedik begitu dalamnya hingga Ma Gedik melakukan balas dendam meskipun ia sudah meninggal. Ia menghancurkan kehidupan keluarga Stammler dari alam orang-orang meninggal.

Roh jahat yang sangat kuat sekali itu kini sedang sangat berbahagia, melihat kemenangankemenangannya, melihat semua dendamnya terbalaskan, meskipun ia harus begitu lama menunggu. "Telah kupisahkan mereka dari orangorang yang mereka cintai," katanya pada Dewi Ayu, "sebagaimana ia memisahkanku dari orang yang aku cintai." (Kurniawan, 2006: 65).

Balas dendam Ma Gedik ini sebagai simbol bahwa subaltern tidak akan tinggal diam dalam ketertindasan. Ia tetap akan melakukan Sesuatu untuk melawan ketertindasan tersebut. Meskipun sepertinya Eka berlebihan dengan memunculkan orang mati dengan tindakan balas dendamnya, tetapi inilah kekuatan orang-orang teraniaya. Mereka akan berjuang sekuat tenaga sampai titik darah penghabisan.

Tak diragukan lagi, banyak di antara kita pernah membayangkan pembalasan dendam atau melabrak orang-orang yang telah melukai kita. Ketika balas dendam dilakukan, ada semacam kelegaan. Balas dendam merupakan pemicu emosional yang membangkitkan orang untuk bertindak. Balas dendam adalah pengalaman yang sangat dapat dirasakan dalam kehidupan manusia, orang-orang setiap kalangan masyarakat paham tentang kemarahan yang membuat seseorang ingin menyakiti orang lain yang telah merugikan.

\section{Jalan Keluar}

Realita sosial kehidupan bangsa ini sudah sangat memrpihatinkan. Keadaan kekerasan ini yang diangkat oleh Kurniawan melalui novel-novelnya. Dalam beberapa hal dikemukakan bahwa jalan keluar untuk menyelesaikan kebiadaban (kekerasan) dalam bangsa ini melalui beberapa cara diantaranya melalui pendidikan, religius, sabar dan saling tolong-menolong.

Sebagai cara jalan keluar dari masalah sosial berupa kekerasan adalah dengan pendidikan. Karena pendidikan mampu meminimalisir untuk melakukan tindakan kekerasan. Seperti halnya yang disampaikan oleh Kurniawan, siapa saja, di mana saja semua manusia harus menyempatkan untuk belajar. Karena belajar mempunyai tujuan mulia. Tokoh Maya Dewi dalam penggalan novel Cantik Itu Luka mendeskripsikan bahwa sesibuk apapun, sebanyak kegiatan apapun, hendaknya tetap sekolah / belajar, seperti data (45) berikut :

Di sela-sela kesibukannya sekolah dan mengerjakan pekerjaan rumah yang dibebankan guru-gurunya, Maya Dewi dengan tekun mengerjakannya. (Kurniawan, 2015:321)

Dari kutipan di atas, menunjukkan bahwa betapa pentingnya pendidikan untuk kehidupan bermasyarakat. Karena pendidikan adalah dua elemen penting dalam sistem sosial politik di setiap negeri, baik negara maju maupun negara berkembang. Pada hakikatnya, kedua elemen tersebut sering dilihat sebagai bagian-bagian yang terpisah dan tidak memiliki hubungan apa-apa. Namun ketika ketika dikaji secara mendalam beradasarkan realitas sosial yang trejadi, maka kita bisah menarik benang merah bahwa kedua elemen tersebut bahumembahu dalam proses pembentuk karakteristik masyarakat di suatu negara. Lebih dari itu, keduanya saling menunjang dan saling mengisi. Lembagalembaga dan proses penjadian berperan penting dalam membenntuk perilaku politik di negara tersebut. Begitu juga sebaliknya, lembaga-lembaga dan proses politik di suatu negara membawa dampak besar pada karakteristik pendidikan di negara tersebut. Menurut Sirozi, (2005: 1) bahwa ada hubungan erat dan dinamis antara pendidikan dan politik di setiap 
negara. Hubungan tersebut adalah realita empirik yang telah terjadi sejak awalawal perkembangan pradaban manusia dan menjadi perhatian para ilmuan. Pandangan tersebut, mempertegas bahwa politik dan pendidikan merupakan dua elemen yang saling mempengaruhi dan bahu-membahu dalam membentuk karakter atau pola pikir dan sikap masyarakat.

Pada lingkungan tertentu orientasi shalat pada zaman modern jarang yang melakukan. Semua manusia memburu harta benda, memburu kekayaan, memburu kenikmatan. Untuk mendapatkan semua itu tentu dilakukan dengan berbagai cara. Hingga lupa kewajiban untuk mendirikan shalat. Kurniawan mengangkat sebuah masalah sosial tersebut dalam novel $O$. Dimana ketika $O$ mendapatkan masalah bertubitubi ia lupa dengan shalat. Namun pada suatu malam menjelang pagi ketika semua teman-temanya istirahat ada yang menyuruh untuk mendirikan shalat seperti pada kutipan berikut :

Hari masih gelap dan seseorang berteriak kencang, "Dirikan salat! Dirikan salat!" Betalumur, yang tidur seperti beton, bergeming. Masih mendengkur dengan mulut terbuka lebar, dan iler mengalir ke sebelah kiri pipinya. Hanya $O$ yang terbangun dan bertanya-tanya, siapa yang berteriak di waktu subuh seperti itu. Tak pernah ada yang berteriak-teriak sebelumnya. "Dirikan salat! Dirikan salat!" O mencoba mencari-cari. Tapi hari masih sangat gelap, sementara lampu satu-satunya yang ada di lantai gedung itu tak cukup menerangi banyak tempat. "Dirikan salat! Dirikan salat!(Kurniawan, 2016: 85)

Suara seruan untuk mendirikan shalat semakin keras. O masih mencari dan mencari dari mana arah suara itu. Namun disela-sela berpikir siapa yang berteriak yang mengajak shalat, $\mathrm{O}$ berpikir bahwa shalat itu bukan kewajiban melainkan kebutuhan. Karenan hakikat mahluk di bumi ini saling membutuhkan. Ketika masalah bertubi-tubi kita disuruh pasrah dan berdoa kepada pencipta. Maka segeralah dengan cepat $\mathrm{O}$ bangun, kemudian melaksanakan shalat. Akhirya $\mathrm{O}$ sering melakukan shalat.

Sebagai bentuk yang menjadi solusi dari masalah kekerasan adalah dengan bersabar. Bersabar sangat penting untuk segala urusan. Seperti halnya yang disampaikan oleh pengarang dalam kutipan novel Seperti Dendam Rindu Harus Dibayar Tuntas sebagai berikut :

"Aku akan bersabar menunggunya, seperti kau bersabar menungguku bangun, Tuan. Bolehkan sementara menunggu, aku tidur lagi?" (Kurniawan, 2016:243)

Pada kutipan di atas, Ajo Kawir adalah pemuda dengan banyak masalah. Mulai dari hidup sebatang kara, miskin, dan selalu disiksa oleh polisi. Karena saking sadisnya cara polisi menyiksa, hingga akhirnya punya masalah dengan kemaluannya. Tetapi, dia terus bersabar menghadapi bertubi-tubi masalah. Tentunya sahabat dan paman yang selalu mengajarkan untuk bersabar. Kadang sesekali ia marah, bahkan dendam kepada siapa saja yang berusaha menyiksanya. Itu karena faktor teman dan lingkungan. Namun karena mempunyai niatan untuk bisa mengatasi dari kerasnya lingkungan, ia selalu mencoba selalu bersabar. Termasuk bersabar dengan perempuan yang ia cintai, juga sabar menunggu psiokologi yang mengganggunya.

Sebagai jalan keluar dari banyaknya masalah kekerasan. Penulis memaparkan tentang masalah dan juga solusi. Solusi atau jalan keluar telah disampaikan oleh penulis bahwa dalam keadaan apanpun dan dimanapun hendaknya kita saling tolong-menolong kepada siapa saja seperti kutipan novel Kurniawan yang berjudul $\mathrm{O}$ sebagai berikut :

Ia menjerit-jerit meminta tolong. Pada saat yang sama, monyet-monyet di dahan dan 
ranting pohon juga menjerit-jerit, kali ini semakin riuh. (Kurniawan: 203)

Setelah perjalanan panjang, $\mathrm{O}$ berusaha keluar dari beberapa masalah. Singgah dari satu tempat ke tempat lain adalah cara untuk sedikit mengurangi keadaan kekerasan yang dialami. Pada saat yang berbeda, ia sadar bahwa tolongmenolong adalah jalan yang paling tepat untuk saling membantu menyelesaikan masalah dari derita yang ia derita sekian lamanya.

Keadaan yang dialami dalam keadaan sosial $\mathrm{O}$ adalah benar realita sosial bangsa ini. Penulis berusaha melalui novelnya, memberikan deskripsi kepada pembaca. Sebagai solusi untuk segera menyelesaikan masalah kebiadaban (kekerasan) adalah tolong menolong atau prososial. Rushton (dalam Sears. dkk, 2005) mengemukakan bahwa perilaku prososial berkisar dari tindakan altruisme yang tidak mementingkan diri sendiri atau tanpa pamrih sampai tindakan menolong yang sepenuhnya dimotivasi oleh kepentingan diri sendiri. Lebih jelasnya, menurut Faturochman (2006) pengertian perilaku prososial sedikit berbeda dengan altruisme, yaitu dengan lebih menekankan pada adanya keuntungan pada pihak yang diberi pertolongan. Perilaku prososial didefinisikan sebagai perilaku yang memiliki konsekuensi positif pada orang lain. Bentuk yang paling jelas dari prososial adalah perilaku menolong.

\section{SIMPULAN}

Kebiadaban dalam tetralogi novel Eka Kurniawan menggunakan kajian stilistika dan sosiologi sastra. Diuraian hubungan antara fenomena sosial dalam teks dan fenomena dalam masyarakat. Pendeskripsian digunakan teori heurmeneutik dan mimesis. Teori heumeneutik digunakan untuk menafsirkan makna dalam teks. Teori mimesis digunakan untuk mencari hubungan antara teks dengan kehidupan nyata. Lingkungan sosiologi yang keras dapat digambarkan dengan bahasa-bahasa yang digunakan oleh pengarang, bahasa yang digunakan adalah bahsa vulgar atau minoritas.

Dalam tetralogi novel karya Eka Kurniawan, ditemukan banyak kekerasan yang terjadi dalam masyarakat. Adapun bentuk-bentuk kekerasan atau kebiadaban yang terjadi adalah penipuan, penindasan, penyiksaan, pemerkosaan, dan pembunuhan.

Pandangan dunia pengarang yang disampaikan pengarang dalam tetralogi novel yang digambarkan adalah kekuasaan, tipu daya dan penderitaan. Sementara dampak kebiadaban yang dilakukan yang dideskripsikan dalam tetralogi novel Kurniawan adalah memunculkan balas dendam, pertengkaran atau saling rebut, dan pembunuhan. Adapun sebagai selusi yang disampaikan penulis dalam tetralogi novel adalah melalui pendidikan, religius, sabar dan saling tolong menolong.

Dari segala bentuk-bentuk kebiadaban manusia mulai dari penipuan, penindasan, penyiksaan, pemerkosaan, dan pembunuhanadalah menderitakan manusia. Dari bentuk kebiadaban ini kemudian muncul dampat kebiadaban manusia. Di antara dampaknya adalah balas dendam, pertengkaran / saling rebut dan pembunuhan.

Eka Kurniawan dalam tetraloginya tidak hanya mengungkap peristiwa di bangsa ini. Ia juga memberikan jalan keluar dari fenomena yang ada. Eka berharap bangsa ini adalah bangsa yang selalu damai, tenteram, tidak ada keributan di mana-mana. Solusi yang ia berikan adalah sebagai bangsa yang damai adalah bangsa yang pendidikannya berjalan baik, religius, sabar dan saling menolong. 


\section{DAFTAR PUSTAKA}

Aliah Darma, Yoce. 2007.Analisis Wacana Kritis. Bandung:Yrama Widya.

Al-Ma'ruf, Ali Imron. 2009. Stilistika Teori, Metode, dan Aplikasi Pengkajian Estetika Bahasa. Solo: Cakra Books.

Aminudin. $1990 . \quad$ Pengembangan Penelitian Kualitatif dalam Bidang Bahasa. Bandung : Angkasa.

Departemen Agam RI. 2010. Alquran dan terjemahan. Semarang. CV Toha Putra.

Kurniawan, Eka. 2015. Cantik Itu Luka. Jakarta: PT Gramedia Pustaka Utama. . 2016. Lelaki Harimau. Jakarta: PT Gramedia Pustaka Utama. . 2016. O. Jakarta: PT Gramedia Pustaka Utama. . 2016. Seperti Dendam Rindu Harus Dibayar Tuntas. Jakarta: PT Gramedia Pustaka Utama.

Mahfud. 1997. Pengantar Ilmu-Ilmu Sosial. Jakarta: Sinar harapan.

Marpaung, Leden. 1999. Tindak Pidana Terhadap Nyawa Dan Tubuh. Jakarta: Sinar Rafika.

Meliala, Adrianus. 2006. Kriminologi Tindak Pidana, Jakarta: Gramedia Cipta.

Moleong. Lexy J. 2011. Metodologi Penelitian Kualitatif. Bandung : Remaja Rosdakarya.

Nurgiyantoro, Burhan. 2005. Teori Pengkajian Fiksi. Yogyakarta: Gajah Mada Press.

Sangidu. 2004. Penelitian Sastra: Pendekatan, Teori, Metode, dan Kiat.Yogyakarta: UGM Press.
Sariban, 2015. Penelitian Sastra Teori dan Penerapan. Surabaya: Lentera Cendekia.

Teeuw, A. 2013. Sastra dan Ilmu Sastra. Bandung : Pustaka Jaya. 


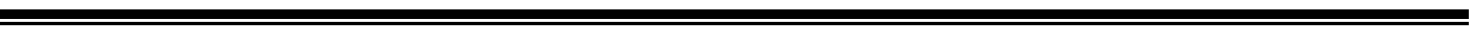

